\title{
Phylogenetic position of freshwater and marine Sigmoidea species: introducing a marine hyphomycete Halosigmoidea gen. nov. (Halosphaeriales)
}

\author{
E.B. Gareth Jones, ${ }^{1, *}$, Alga Zuccaro², Julian \\ Mitchell $^{3}$, Akira Nakagiri ${ }^{4}$, Ittichai Chatmala ${ }^{1,5}$ \\ and Ka-Lai Pang ${ }^{1,6}$ \\ ${ }^{1}$ BIOTEC Bioresources and Technology Unit, National \\ Center for Genetic Engineering and Biotechnology, \\ 113 Paholyothin Road, Khlong 1, Khlong Luang, \\ Pathum Thani 12120, Thailand, \\ e-mail: remispora@googlemail.com \\ ${ }^{2}$ Research Center for BioSystems, Land Use and \\ Nutrition IFZ, Institute of Phytopathology and Applied \\ Zoology (IPAZ), Justus-Liebig-University Giessen, \\ 35392 Giessen, Germany \\ ${ }^{3}$ School of Biological Sciences, University of \\ Portsmouth, King Henry Building, King Henry I Street, \\ Portsmouth PO1 2DY, UK \\ ${ }^{4}$ National Institute of Technology and Evaluation, \\ Biological Resource Center, 2-5-8, Kazusalamatari, \\ Kisarazu-shi, Chiba, 292-0818, Japan \\ ${ }^{5}$ Department of Microbiology, Faculty of Science, \\ Prince of Songkla University, Hat Yai, Songkhla, \\ Thailand \\ ${ }^{6}$ Institute of Marine Biology, National Taiwan Ocean \\ University, No. 2 Pei-Ning Road, Keelung 20224, \\ Taiwan (R.O.C.) \\ * Corresponding author
}

\begin{abstract}
The aquatic hyphomycete genus Sigmoidea, with freshwater and marine representatives, is re-examined at the morphological and molecular levels. Currently six species are accepted, four from freshwater habitats (S. prolifera, S. aurantiaca, S. contorta, S. praelonga) and two marine species (S. marina, S. luteola). Phylogenetic analyses of the ribosomal small subunit rRNA gene sequences of freshwater and marine Sigmoidea species indicate that the marine species are distantly placed from the freshwater species, S. prolifera and Pseudosigmoidea cranei. The latter species are placed in the Dothideomycetes, in sister clades, with $81 \%$ bootstrap support. The phylogenetic placement of both marine Sigmoidea species, inferred from large subunit rRNA gene sequences, was within the genus Corollospora (Halosphaeriales, Sordariomycetes, Pezizomycotina). An undescribed Sigmoidea species isolated from the Baltic Sea and one previously incorrectly identified as $S$. marina from Japan (S. parvula sp. nov.) formed a clade together with Corollospora quinqueseptata and Varicosporina ramulosa, and were located in a sister group to S. luteola and S. marina. Based on morphological and phylogenetic evidence, Halosigmoidea gen. nov. is proposed to accommodate the
\end{abstract}

three marine Sigmoidea species (S. luteola, S. marina, S. parvula sp. nov.). Identification keys to the genera Halosigmoidea, Pseudosigmoidea and Sigmoidea, and Halosigmoidea species are provided.

Keywords: 18S; 28S; Corollospora; Halosigmoidea gen. nov.; Halosphaeriales; ITS rDNA; marine fungi; Sigmoidea.

\section{Introduction}

Crane (1968) established the genus Sigmoidea for a submerged freshwater hyphomycete with hyaline, scolecoform conidia, Sigmoidea prolifera (R.H. Petersen) J.L. Crane that was originally placed in the genus Flagellospora Ingold by Petersen (1963). The establishment of the genus Sigmoidea was based on the presence of holoblastic rather than phialidic conidiogenous cells (Crane 1968, Marvanová and Descals 1987). Since then, three additional freshwater species have been described: S. aurantiaca Descals, a taxon having wide falcate to sigmoid shaped conidia (Descals and Webster 1982); S. praelonga Marvanová, from Czech waters, with longer conidia than S. prolifera (Marvanová 1986) and S. contorta Marvanová et Hywel-Jones, a pleoanamorphic species with macroconidia that have sympodial or rarely percurrent conidiogenous cells and polyblastic microconidia borne on contorted thick-walled hyphal branches (Marvanová and Hywel-Jones 2000).

Crane (1968) erected the genus Sigmoidea using Petersen's holotype specimen preserved in NY as type. However, Crane's specimen, 85-B-65 (=ATCC 16660), also deposited as $S$. prolifera, differed from the type in not showing ampulliform sympodially elongating conidiogenous cells (Marvanová and Descals 1987). In 2000, Ando and Nakamura transferred Crane's specimen to a new genus, Pseudosigmoidea K. Ando et N. Nakamura with $P$. cranei K. Ando et N. Nakamura, as the type species (ATCC 16660), based on the presence of polyphialdic enteroblastic conidiogensis. Although there is no doubt that these two specimens represent two different taxa, there is no evidence of polyphialdic enteroblastic conidiogenesis from the illustrations in the protolog by Ando and Nakamura, and there is no indication of repeated production of conidia from the same conidiogenous locus. The taxonomic position of these specimens therefore remains unclear.

Two additional Sigmoidea species with sympodial conidiogenesis cells, curved (not sigmoid as indicated in the original descriptions) conidia with the end cells lacking cytoplasmic contents were described: Sigmoidea marina Haythorn et E.B.G. Jones (Haythorn et al. 1980) 
and Sigmoidea luteola Nakagiri et Tubaki (Nakagiri and Tubaki 1982). The teleomorph of S. luteola is Corollospora luteola Nakagiri et Tubaki (Nakagiri and Tubaki 1982), while no teleomorph is known for S. marina. An additional Sigmoidea species, S. littoralis Phillips, collected from decomposing material of the red alga Gelidium coulteri Harv., from Hopkins Marine Station, Pacific Grove, California in 1979, was listed in Index fungorum (CABI website, this reference has now been removed), but to our knowledge a description of this species has never been published nor has an isolate been deposited anywhere. Additional collections were made from Rhodoglossum affine (Harv.) Kyl. in California and Prasiola meridionalis S. et G. at Cattle Point, San Juan Island, Washington (G.K. Phillips, personal communication); unfortunately, no specimens or isolates are available for morphological or molecular analysis.

During a study of fungi associated with marine plants and algae in Germany, many isolates belonging to the genus Sigmoidea were recovered from Fucus serratus $\mathrm{L}$. collected on Helgoland, North Sea (Zuccaro et al. 2003, 2008) and identified as Sigmoidea marina. Others collected from a variety of substrata located at different sites in the Baltic Sea also could not be identified according to the descriptions of known species (Crane 1968, Haythorn et al. 1980, Descals and Webster 1982, Nakagiri and Tubaki 1982, Marvanová 1986, Marvanová and Descals 1987, Marvanová and Hywel-Jones 2000). These isolates, together with three Sigmoidea sp. (originally identified as S. marina) collected from sea foam in Japan, shared several morphological characteristics typical of $S$. marina, but differed by having shorter conidia (Nakagiri 1989). Because the marine Sigmoidea species are morphologically different from S. prolifera in having predominantly C- or U-shaped conidia with end cells lacking cytoplasm, irregular sympodial conidiogensis cells, and are marine in habitat, a molecular phylogenetic study was undertaken to resolve the taxonomic relationship between the freshwater and marine species.

\section{Materials and methods}

\section{Fungal cultures}

Fungi used in this study are Corollospora luteola NBRC 31315 (ex-type) isolated from ascospores in sea foam (Nakagiri 1989), Pseudosigmoidea cranei ATCC 16660 (ex-type), Sigmoidea prolifera CCM F-10002 (isolated and kindly donated by Dr. Ludmilla Marvanová), Sigmoidea marina NBRC 103271 (=AN-690, G. Jones, PP 0423 ex-type), and Sigmoidea sp. Japan (Halosigmoidea parvula) NBRC 32159, NBRC 32160, and NBRC 103558 (ex A. Nakagiri). Isolates TUB 6582, TUB 6989, and TUB 407 of the undescribed Sigmoidea sp. (H. parvula) were collected, respectively, from Ahrenshoop, Wismar, and Travemunde sites in the Baltic Sea in September 2002, March 2003, and May 2004. Two of the isolates (TUB 6582 and TUB 407) were recovered from red algae (Polysiphonia sp. and Ceramium sp., respectively) and one (TUB 6989) from the seagrass Zostera marina L. All cultures recovered from algae were isolated after surface sterilization of host material (method described in Zuc- caro et al. 2003). Ten strains of S. marina (Halosigmoidea marina), were isolated from Fucus serratus thalli collected during a study on Helgoland, North Sea, of which TUB 270 was used in this study. TUB 156, isolated from Norddeich, North Sea was also used in this study. Two Sigmoidea sp. isolates (TUB 7952 and TUB 7956) were isolated from Enteromorpha sp. from Niendorf, Baltic Sea. Four isolates of Corollospora angusta Nakagiri et Tokura were isolated from $F$. serratus collected from Helgoland, North Sea, but only TUB 1 was used in this study. Other freshwater Sigmoidea species were not available to us for study as existing isolates were subject to commercial confidentiality.

Fungi were maintained on freshwater or seawater cornmeal agar (Difco, Criterion, Santa Maria, USA: $30 \mathrm{~g}$ $\mathrm{I}^{-1}$ maize meal, $20 \mathrm{~g} \mathrm{l}^{-1}$ agar) as appropriate. Cultures were grown in GYP broth (homemade: $4 \mathrm{~g} \mathrm{l}^{-1}$ glucose, $4 \mathrm{~g} \mathrm{l}^{-1}$ yeast extract, $2 \mathrm{~g} \mathrm{l}^{-1}$ peptone) in filtered natural seawater except for Sigmoidea prolifera and Pseudosigmoidea cranei, which were grown in a CMA freshwater medium. Fungal biomass was harvested by filtration and washed with sterile distilled water.

Isolates TUB 6989 and TUB 407 were cultured on artificial seawater (Meersalz, Wiegandt $\mathrm{GmbH}$, Krefeld, Germany) glucose-peptone-yeast extract agar GYP $\left(0.1 \mathrm{~g} \mathrm{l}^{-1}\right.$ glucose, $0.1 \mathrm{~g} \mathrm{l}^{-1}$ yeast extract, $0.5 \mathrm{~g} \mathrm{l}^{-1}$ peptone, $20 \mathrm{~g} \mathrm{l}^{-1}$ agar, $15 \mathrm{~g} \mathrm{l}^{-1}$ sea salt) at 14,20 , and $25^{\circ} \mathrm{C}$ in the dark for morphological description. For molecular analysis, these two isolates were grown on glucose-peptone-yeast extract agar $\left(0.1 \mathrm{~g} \mathrm{l}^{-1}\right.$ glucose, $0.1 \mathrm{~g} \mathrm{l}^{-1}$ yeast extract, $0.5 \mathrm{~g} \mathrm{l}^{-1}$ peptone, $20 \mathrm{~g} \mathrm{l}^{-1}$ agar, $15 \mathrm{~g} \mathrm{l}^{-1}$ sea salt) at room temperature for 1 week.

\section{DNA isolation and PCR amplification}

For the strains isolated from Germany, up to $500 \mathrm{mg}$ of fresh mycelium was removed from the surface of the agar plates with a sterile loop and extracted using the FastDNA SPIN Kit for soil (BIO 101 Systems, MachereyNagel, Düren, Germany). DNA fragments were used as templates for the polymerase chain reaction (PCR) using the 28S rDNA primers NL209-NL912 (Zuccaro et al. 2003) or the ITS primers ITS1-ITS4 (White et al. 1990). PCR amplifications were performed on a Biometra T personal PCR system (Göttingen, Germany) as described by Zuccaro et al. (2003). The PCR samples were purified using a GENECLEAN III Kit (BIO 101 Systems) and run in an agarose gel together with a custom-made standard to check the DNA concentration. Cleaned PCR products were sequenced using the fluorescent method in a $\mathrm{Li}$ COR 4200 DNA sequencer (Lincoln, NE, USA).

The cetyl-trimethyl-ammonium-bromide (CTAB) method for genomic DNA extraction (Jones et al. 2006) was used to obtain DNA from the remaining strains.

The nuclear small subunit rRNA gene was amplified from genomic DNA using the primers NS1/NS6 (or /NS4) and NS5/NS8 (or /ITS4) (White et al. 1990), whereas the large subunit rRNA gene was amplified using primers JS1/JS8 (or /LR7) (Bunyard et al. 1994, Landvik 1996). Both SSU and LSU rDNA were amplified using a FINNZYMES, DyNAzyme ${ }^{\mathrm{TM}}$ II DNA Polymerase Kit (MachereyNagel, product code F-551S) in a Perkin Elmer thermal cycler (P.E. Applied Biosystems, USA). The amplification 
cycle consisted of an initial denaturation step at $94^{\circ} \mathrm{C}$ for 5 min followed by 35 cycles of (i) denaturation $\left(94^{\circ} \mathrm{C}\right.$ for $1 \mathrm{~min}$ ) (ii) annealing ( $55^{\circ} \mathrm{C}$ for $\left.1.5 \mathrm{~min}\right)$, and (iii) elongation $\left(72^{\circ} \mathrm{C}\right.$ for $2.5 \mathrm{~min}$ ), and a final $10 \mathrm{~min}$ elongation step at $72^{\circ} \mathrm{C}$. The PCR products were analyzed by agarose gel electrophoresis and purified using a NucleoSpin ${ }^{\circledR}$ Plant DNA Purification Kit (Macherey-Nagel, Catalogue No. 740 570. 50).

\section{DNA sequencing}

Direct sequencing of purified PCR products was performed using NS1, NS2, NS3, NS4, NS5, and NS8 of SSU rDNA (White et al. 1990), while JS1, JS5, JS8, and LR7 were used to sequence the LSU rDNA (Landvik 1996) with an ABI PRISM dRhodamine Terminator Cycle Sequencing Kit (Macrogen Inc., Korea). Reactions and programs were chosen according to the manufacturer's recommendations. Samples were analyzed automatically by the BIOTEC Service Unit (BSU, Pathumthani, Thailand) laboratory or using the fluorescent method in a Li-COR 4200 DNA sequencer.

\section{Sequence alignment and phylogenetic analysis}

After sequence assembly, sequences were aligned manually in Se-Al v1.0a1 with other sequences obtained from GenBank (Rambaut 1999). Three datasets, SSU, LSU, and ITS-5.8S rDNA were analyzed in PAUP 4.0b10 using maximum parsimony and maximum likelihood criteria (Swofford 2002).

For the SSU dataset, 59 taxa were included. A unique insertion of 282 bases in Pseudosigmoidea cranei ATCC 16660 was excluded from analysis (Figure 1). Candida atlantica (Siepmann) S.A. Mey et Simione and Kluyveromyces aestuarii (Fell) van der Walt were designated as the outgroup taxa. The best tree(s) under parsimony criterion was (were) found through a heuristic search [starting tree via stepwise addition, 100 replicates of random sequence addition, tree-bisection-reconnection (TBR) branch-swapping algorithm]. Support of the clades was estimated by 1000 parsimony bootstrapping through a heuristic search (starting tree via stepwise addition, 10 replicates of random sequence addition, TBR).

For the LSU dataset, 18 taxa were included, with Petriella setifera (J.C. Scmidt) Curzi and Microascus trigonosporus C.W. Emmons et B.O. Dodge as the outgroup taxa. The best tree(s) under parsimony criterion was (were) found through a heuristic search (starting tree via stepwise addition, 100 replicates of random sequence addition, TBR branch-swapping algorithm) (Figure 2). Support of the clades was estimated by 1000 parsimony bootstrapping through a heuristic search (starting tree via stepwise addition, 10 replicates of random sequence addition, TBR).

The ITS-5.8S rDNA dataset comprised 12 taxa belonging to the genera Sigmoidea and Corollospora for 743 nucleotides covering both ITS regions and the 5.8S rRNA gene, and two sequences from Ceriosporopsis halima Linder as the outgroup taxon. Maximum likelihood and parsimony analyses were performed using this dataset. In both analyses, absent sequence information was treated as missing. For the maximum likelihood analysis, a user-specified substitution matrix, calculated from the data matrix, and an estimated shape parameter were used, consistent with a GRT $+\mathrm{G}$ model. The maximum parsimony analysis was conducted using a heuristic search with random stepwise sequence addition (10 replicates) and TBR branch-swapping. Support for clades was estimated by bootstrapping (100 replicates) through heuristic searches (starting tree via stepwise addition, 10 replicates of random sequence addition).

\section{Results}

\section{Phylogenetic analysis}

The SSU dataset comprised 2122 characters with 455 parsimony-informative characters. In order to determine the ordinal affinity of the freshwater and marine Sigmoidea species, sequences from representative orders of the Dothideomycetes and Sordariomycetes were analyzed with those of Pseudosigmoidea cranei, Sigmoidea prolifera, Corollospora luteola, Sigmoidea marina (Halosigmoidea marina), and Sigmoidea sp. (Halosigmoidea parvula). Two most parsimonious trees (MPTs) resulted (tree length $=1759$, C.I. $=0.5088$, R.I. $=0.7078$ ) and the consensus tree is shown in Figure 1.

Both Pseudosigmoidea cranei and Sigmoidea prolifera are positioned in the Dothideomycetes. These two species occur in a fairly well supported clade $(81 \%)$ with the hyphomycetes Helicoon fuscosporum Linder, Troposporella fumosa P. Karst., and Phaeotrichum benjaminii Malloch et Cain (Phaeotrichaceae). The relationship between these taxa and other orders of the Dothideomycetes is unclear, as indicated by the low bootstrap values on the internal branches.

Monophyly of the Sordariomycete taxa is well supported $(100 \%)$ and the marine Sigmoidea species are distantly related to the freshwater Sigmoidea species and reside in the order Halosphaeriales (Figure 1). Corollospora luteola, Sigmoidea sp. Japan (Halosigmoidea parvula) and Sigmoidea marina (Halosigmoidea marina) are closely related to the genus Corollospora.

Analysis of the nuclear partial LSU rRNA was used to resolve the phylogenetic affinity of Halosigmoidea spp. (Corollospora/Sigmoidea luteola, Sigmoidea marina, Sigmoidea sp. Japan, Sigmoidea parvula) with Corollospora species. The consensus tree of two MPTs is shown in Figure 2 (tree length $=948$, C.I. $=0.6108$, R.I. $=0.6766$ ). This is a strict parsimony consensus tree with 18 isolates and with Petriella setifera and Microascus trigonosporus as an outgroup. All the marine Sigmoidea isolates group within the Corollospora clade with good bootstrap support and fall into two distinct subclades: (1) S. marina is monophyletic with two isolates from Germany and one from the UK (ex-type), with Corollospora angusta Nakagiri et Tokura as a sister group (clade A) with C. luteola basal to clade A. (2) Halosigmoidea parvula strains (clade B) are monophyletic with Corollospora quinqueseptata Nakagiri and Varicosporina ramulosa Meyers et Kohlm. as a sister group, but with weak support (50\%). Two Corollospora maritima Werderm. strains form a monophyletic group (clade $\mathrm{C}$ ), while clade $\mathrm{D}$ contains a range 


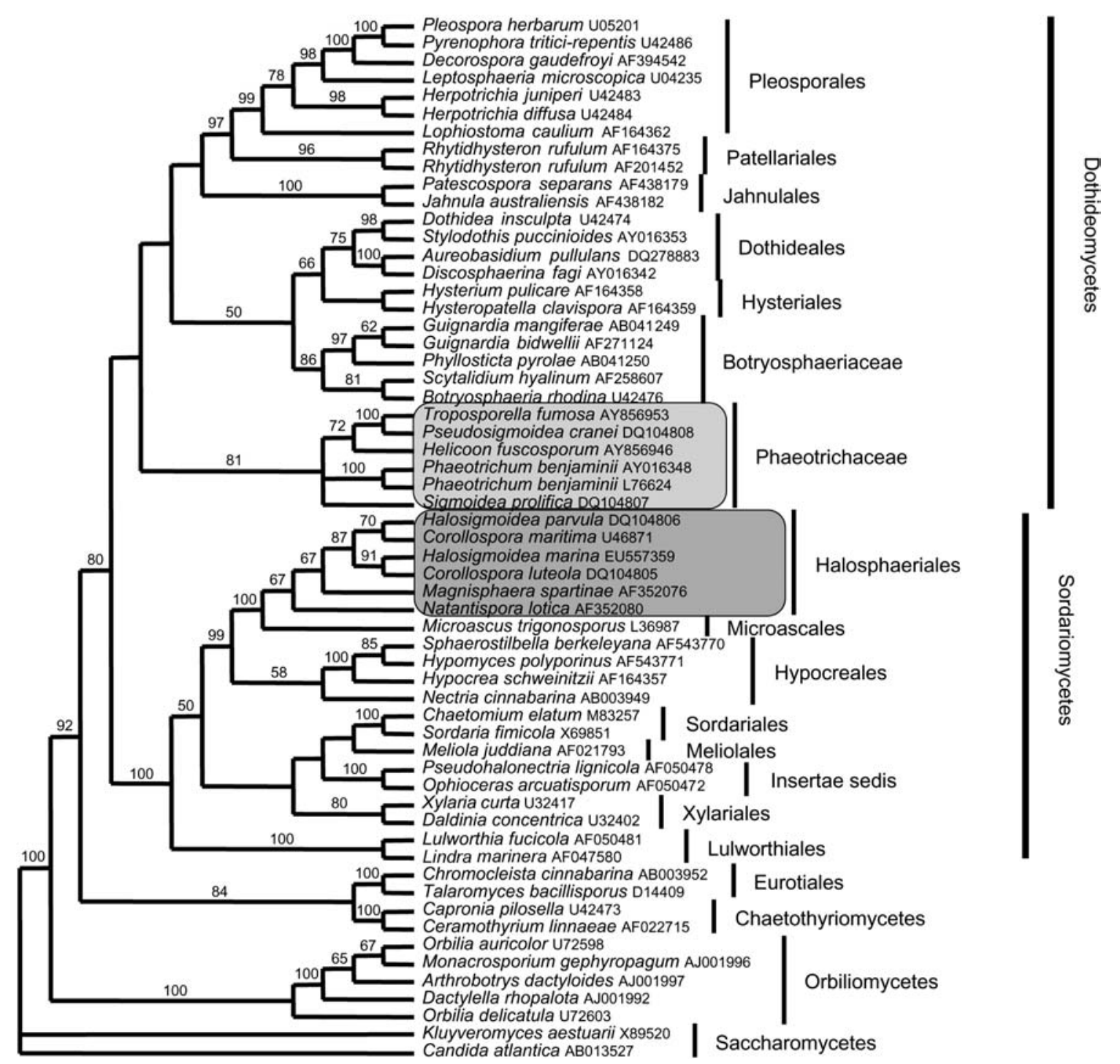

Figure 1 One of the consensus parsimonious trees inferred from SSU rDNA sequences.

Maximum parsimony bootstrap values $\geq 50 \%$ are indicated above the branches.

of Corollospora species, all with phragomoseptate ascospores.

The ITS-5.8S rDNA analysis revealed the cohesiveness of the Halosigmoidea parvula clade compared to clades containing other Halosigmoidea and Corollospora species (Figure 3). The dataset comprised 743 characters with 288 parsimony-informative sites, and it generated two most parsimonious trees of length 547 with C.I. $=$ 0.927, R.I. $=0.934$, R.C. $=0.866$, and H.I. $=0.073$, with Ceriosporopsis halima strains as the outgroup. Maximum likelihood analysis, using the GTR $+\mathrm{G}$ model with estimated nucleotide frequencies and substitution rates, generated a tree with a topology similar to that obtained using parsimony criterion. Both analyses revealed three strongly supported clades: (1) $H$. parvula isolates from Germany and Japan, (2) Halosigmoidea luteola, Halosigmoidea marina, Corollospora intermedia I. Schmidt and Corollospora angusta, and (3) two undescribed Halosigmoidea strains with Corollospora colossa Nakagiri et Tokura. The proportion of site variation between selected Halosigmoidea species is shown in Table 1. Little variation exists between $H$. parvula isolates from Germany and Japan, indicating an extremely close evolutionary relationship, whereas it ranges from 0.29 to 0.34 between other species.

\section{Discussion}

A number of studies deal with the taxonomy, ultrastructure, and phylogeny of Corollospora, a genus with a large number of species in the Halosphaeriales (currently 19, while others await description; E.B.G. Jones, personal observations) (Jones et al. 1983, 2009, Campbell et al. 2002, Hsieh et al. 2007, Abdel-Wahab et al. 2009). However, no clear picture emerges as to the phylogenetic relationships among the various species. Certainly the molecular data suggest that, while Corollospora species form a well-supported monophyletic group, there is great sequence variation within the clade and this may well represent distinct lineages. Morphologically, there is great variation between different taxa in the genus (Jones 1995, Campbell et al. 2002). Even the occurrence of three 


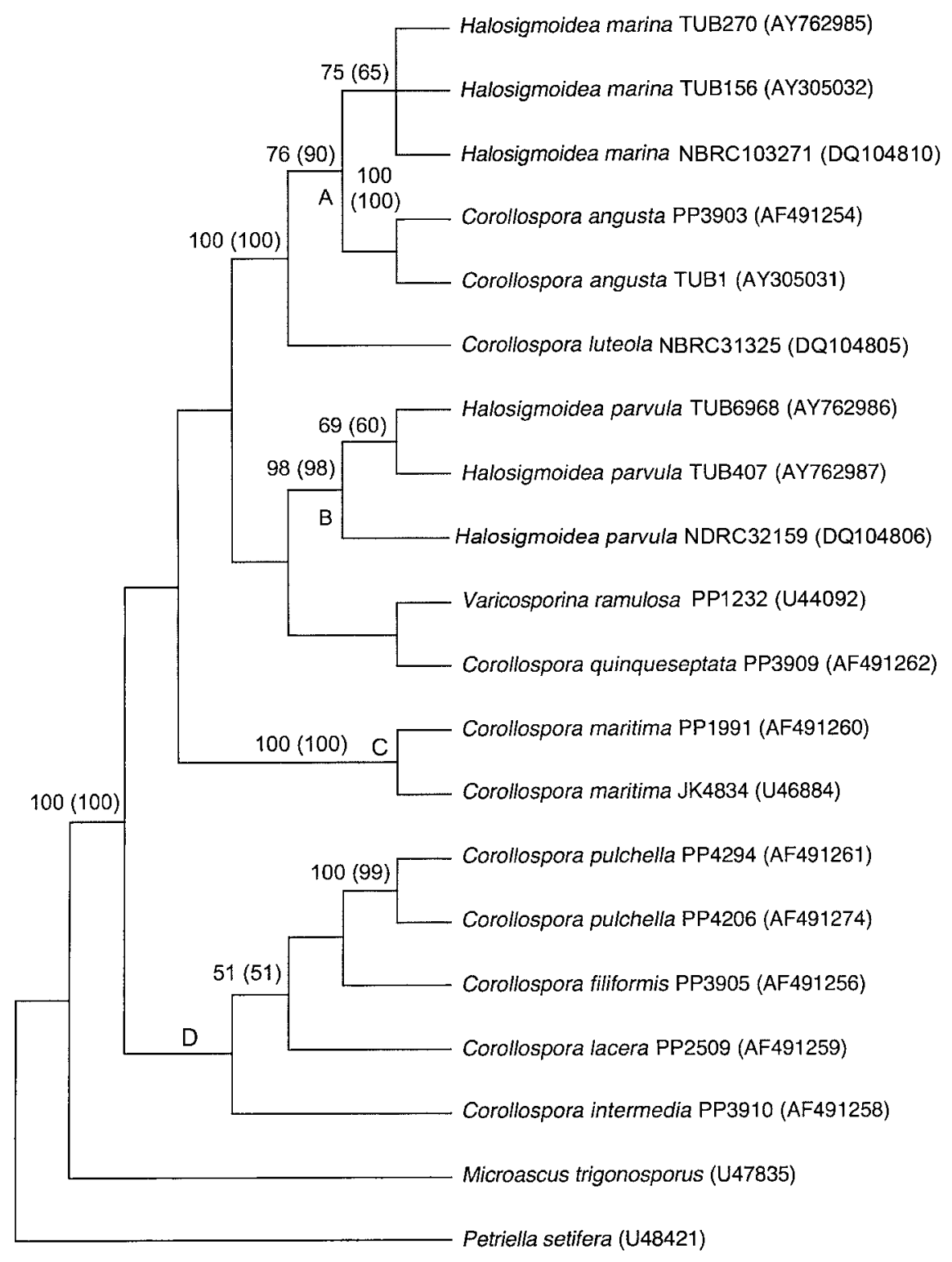

Figure 2 One of the consensus parsimonious trees inferred from LSU rDNA sequences.

Bootstrap values ( $\geq 50 \%$ ) for maximum parsimony values and maximum likelihood analyses (in parentheses) are indicated above the branches.

anamorphic genera within the genus (Clavariopsis, Halosigmoidea, Varicosporina) does not offer the prospect of subdivision of the genus. Data presented in this study (Figure 3) suggest a possible subdivision in the genus, with two unidentified species forming a sister group to Corollospora colossa.

Further studies are required to resolve the phylogenetic relationship of Corollospora species and their anamorphs, using a wider range of taxa, duplicate strains, and more genes.

Morphological and molecular evidence indicates that the marine Sigmoidea species are distantly related to the freshwater species, and we propose the transfer of the marine Sigmoidea luteola and Sigmoidea marina to the new genus Halosigmoidea, and the description of a new species (Halosigmoidea parvula) to accommodate Sigmoidea sp. isolated from Japan (NBRC 32159, 32160, 103558) and the collections made in the Baltic Sea, Germany (407, 6582, 6968, 6989).

\section{Taxonomy}

\section{Sigmoidea J.L. Crane}

Type species Sigmoidea prolifera (R.H. Petersen) J.L. Crane.

\section{MycoBank MB339266.}

Freshwater anamorphic ascomycete (Dothideomycetes) with hyaline, sigmoid or curved or straight, not coiled, and many times septate conidia. Conidiogenous cells not phialidic, as repeated proliferation on at least one locus has not been demonstrated (Descals and Webster 1982).

\section{Pseudosigmoidea Ando et Nakamura}

Type species Pseudosigmoidea cranei Ando et Nakamura. 


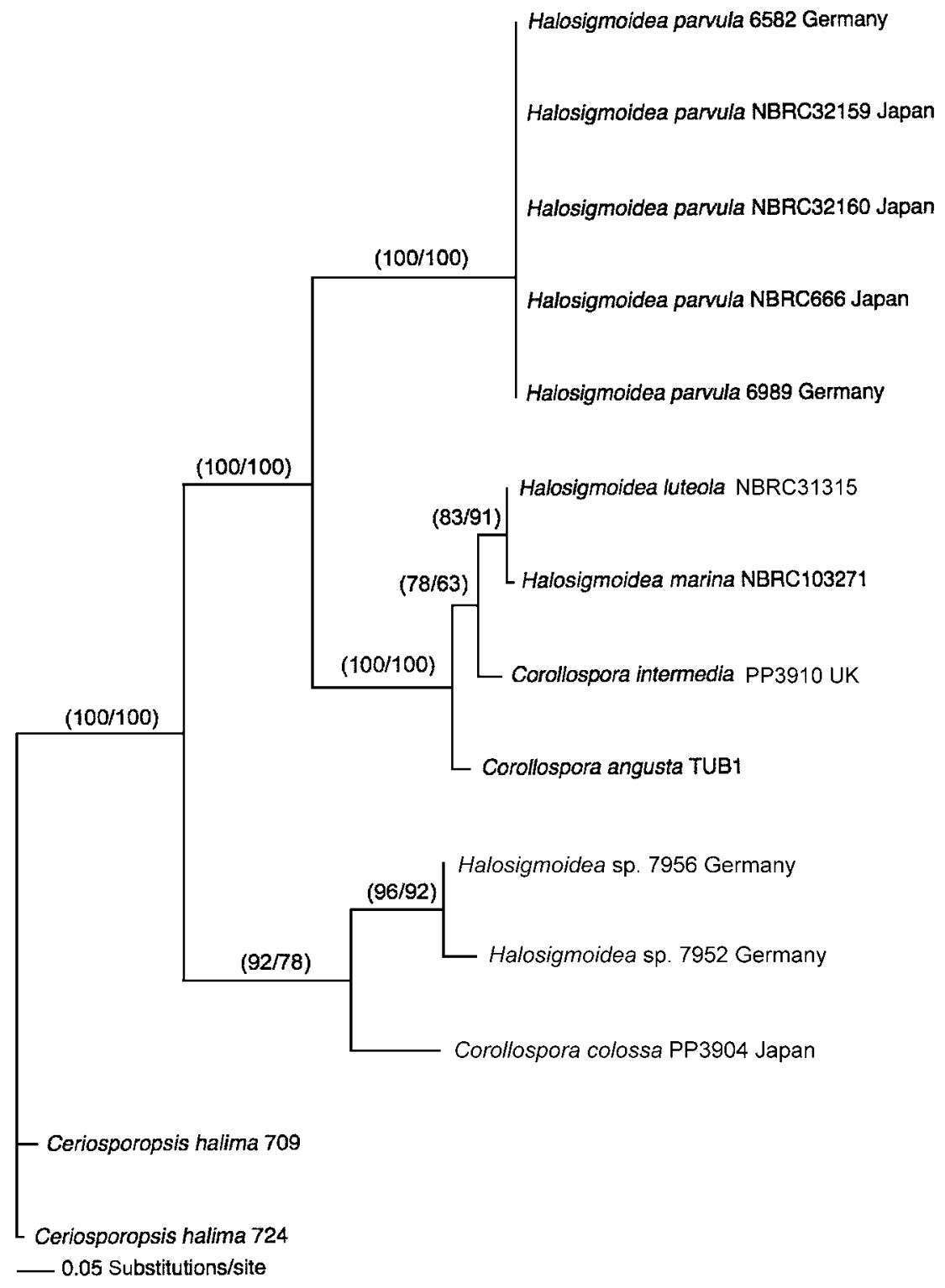

Figure 3 Maximum likelihood tree ( $-\mathrm{L}=3178.73267)$ showing the relationship between Halosigmoidea, Sigmoidea, and Corollospora species using ITS-5.8S rDNA.

Nucleotide frequencies $(A=0.214, C=0.307, G=0.28$, and $T=0.199)$, the substitution rates and shape parameter $(0.546)$ were estimated from the dataset. Bootstrap values ( $\geq 50 \%$ ) for the maximum likelihood and parsimony (in parentheses) analyses are shown above the branches.

Table 1 Proportion of site variation between Halosigmoidea $(H$.$) and Corollospora (C$.) species for 524 aligned nucleotides, estimated using PAUP.

\begin{tabular}{|c|c|c|c|c|c|c|c|}
\hline Fungal strains & $\begin{array}{l}H . \\
\text { parvula } \\
32159\end{array}$ & $\begin{array}{l}H . \\
\text { parvula } \\
32160\end{array}$ & $\begin{array}{l}H . \\
\text { parvula } \\
666\end{array}$ & $\begin{array}{l}H . \\
\text { parvula } \\
6582\end{array}$ & $\begin{array}{l}H . \\
\text { marina } \\
103271\end{array}$ & $\begin{array}{l}\text { Sigmoidea } \\
\text { sp. } 7956\end{array}$ & $\begin{array}{l}\text { C. } \\
\text { angusta } \\
\mathrm{m} 211\end{array}$ \\
\hline H. parvula 32159 & - & 0 & 0 & 0.0019 & 0.2926 & 0.3530 & 0.2809 \\
\hline H. parvula 32160 & & - & 0 & 0.0019 & 0.2926 & 0.3530 & 0.2809 \\
\hline H. parvula 666 & & & - & 0.0019 & 0.2926 & 0.3530 & 0.2809 \\
\hline H. parvula 6582 & & & & - & 0.2949 & 0.3555 & 0.2831 \\
\hline H. marina 103271 & & & & & - & 0.3271 & 0.0958 \\
\hline Sigmoidea sp. 7956 & & & & & & - & 0.3407 \\
\hline C. angusta m211 & & & & & & & - \\
\hline
\end{tabular}

Proportion of sites differing out of 524 sites compared (taking into account gaps). 


\section{MycoBank MB464825.}

Freshwater anamorphic ascomycete (Dothideomycetes) with hyaline conidia, condiogenesis holoblastic with rhexolytic secession of conidia, but no evidence was presented for a frill at the base of the conidium (Marvanová and Descals 1987, Ando and Nakamura 2000). The species was described as having enteroblastic polyphialdic conidiogensis, but there is no evidence of repeated production of conidia from the same locus.

\section{Halosigmoidea Nakagiri, K.L. Pang et E.B.G.} Jones, gen. nov.

\section{MycoBank MB513326.}

Marine anamorphic ascomycetes (Sordariomycetes): Mycelium ex hypis ramosis, sepatis, hyalinis. Conidiophoris hyalinis, pleurogena. Cellulis conidiogenesis holoblasticis, terminalibus vel sympodialiter denticulatis. Conidiis curvati usque ad efficendam volutationem, solitariis, septatis, hyalinis. Habitat marina.

Holotypus generis Halosigmoidea luteola (Nakagiri et Tubaki) Nakagiri K.L. Pang et E.B.G. Jones. This is designated the type of the genus because of its confirmed teleomorph Corollospora luteola Nakagiri et Tubaki.

Holotype NBRC H-12292 (=TKB-F-5002).

Etymology Latin prefix 'Halos' refers to the marine habitat of the fungus.

Marine anamorphic ascomycetes (Sordariomycetes): mycelial hyphae branched, septate, hyaline. Conidiophore hyaline pleurogenous on the mycelium initially short and simple, then becoming longer and septate. Conidiogenous cells holoblastic, terminal, sympodial or irregularly sympodial and denticulate with schizolytic secession. Conidia aleuriospores, C- to U-shaped, rarely sigmoid, solitary, multiseptate, hyaline, terminal and basal cells of mature conidia devoid of cytoplasmic contents when mature. Marine habitat.

Halosigmoidea differs from Sigmoidea in the following way: (1) conidia C- or U-shaped, rarely sigmoid, (2) conidial cells slightly swollen, (3) conidial ends cells lacking cytoplasmic contents, (4) phylogenetically placed in the Halosphaeriales, and (5) marine species found predominantly on decaying seaweeds, especially members of the Fucales (Haythorn et al. 1980, Zuccaro and Mitchell 2006). Mature conidia are generally not constricted at the septa, but before germination, each conidial cell becomes rounded and the filament separates into individual cells or several cell clusters, from which hyphae germinate.

Halosigmoidea luteola (Nakagiri et Tubaki) Nakagiri, K.L. Pang et E.B.G. Jones, comb. nov.

\section{MycoBank MB110080.}

Basionym Sigmoidea luteola Nakagiri et Tubaki. 1982. Trans. Mycol. Soc. Japan 23: 102.

Hyphae branched, septate, hyaline. Conidiophore hyaline, pleurogenous on the mycelium, initially short and simple, then becoming longer, wall smooth and thin.
Conidiogenous cells holoblastic, terminal, sympodial or irregularly sympodial and denticulate schizolytic secession. Conidia aleuriospores, rarely sigmoid, solitary, septate, slightly to moderately constricted at the septa, hyaline, 106-223×5-8 $\mu \mathrm{m}, 7-13(-18)$ septate, end cells of mature conidia devoid of cytoplasmic contents when mature and longer than the other cells in the conidium. Colonies on PDA (200 $\mathrm{g} \mathrm{l}^{-1}$ potatoes, $15 \mathrm{~g} \mathrm{l}^{-1}$ dextrose, $20 \mathrm{~g} \mathrm{l}^{-1}$ agar) with natural filtered seawater moderately to strongly yellow.

Teleomorph is Corollospora luteola Nakagiri et Tubaki, MycoBank: MB109694.

Material examined Japan, Tateyama-shi, Chiba Pref., ascospores isolated from sea foam, 27 February 1981. A. Nakagiri, NBRC 31315 (=ATCC 48862, TKBC-1250) ex-type Corollospora luteola.

Halosigmoidea marina (Haythorn et E.B.G. Jones) Nakagiri, K.L. Pang et E.B.G. Jones, comb. nov.

\section{MycoBank MB114022.}

Basionym Sigmoidea marina Haythorn et E.B.G. Jones. 1980. Trans. Brit. Mycol. Soc. 74: 620.

Hyphae 2-4 $\mu \mathrm{m}$ in diameter, branched, septate, hyaline. Conidiophores hyaline pleurogenous on the mycelium initially short and simple, becoming longer and septate, wall smooth and thin. Conidiogenous cells holoblastic, terminal, sympodial or irregularly sympodial and denticulate. Conidia aleuriospores, C-shaped to slightly sigmoid, solitary, 7-11 septate, somewhat strongly constricted at the septa, hyaline, (80-) 110-180 (-231) $\times$ 4-7 $\mu \mathrm{m}$, end cells conidia devoid of cytoplasmic contents when mature and longer than the other conidial cells. Conidial secession schizolytic. Colonies on PDA (200 $\mathrm{g} \mathrm{l}^{-1}$ potatoes, $15 \mathrm{~g} \mathrm{l}^{-1}$ dextrose, $20 \mathrm{~g} \mathrm{l}^{-1}$ agar) with natural filtered seawater hyaline and pale yellow to orange with age. Teleomorph is unknown; however, molecular sequence data indicate that it should be in the genus Corollospora.

Material studied Ex-type NBRC 103271 (=AN-690, G. Jones PP 0423), TUB 270, and TUB 156.

Halosigmoidea marina differs from Halosigmoidea luteola in that: (1) conidia are more curved, (2) conidia are shorter and narrower, (3) conidia have fewer cells, (4) colonies are orange and slimy, (5) it is isolated from marine algae, and (6) has no known teleomorph.

\section{Halosigmoidea parvula Zuccaro, Mitchell et Nakagiri sp. nov. (Figures 4-6)}

\section{MycoBank MB513327.}

Colonia in cultura agarosa tardo incremento, $10 \mathrm{~mm}$ in 7 dies expandente. Principio colonarium subalbo colore, temporis decursu colore pallente-fusco. Insensibilis odor. Copiosa sporulatio sine demersione in aqua. Compactum mycelium sine aerio mycelio. Crassae hyphae 1.5$2.5 \mu \mathrm{m}$ plerumque immersae in medio, hyalinae, septatae, ramosae, non costrictae ad septa. Interdum anasto- 

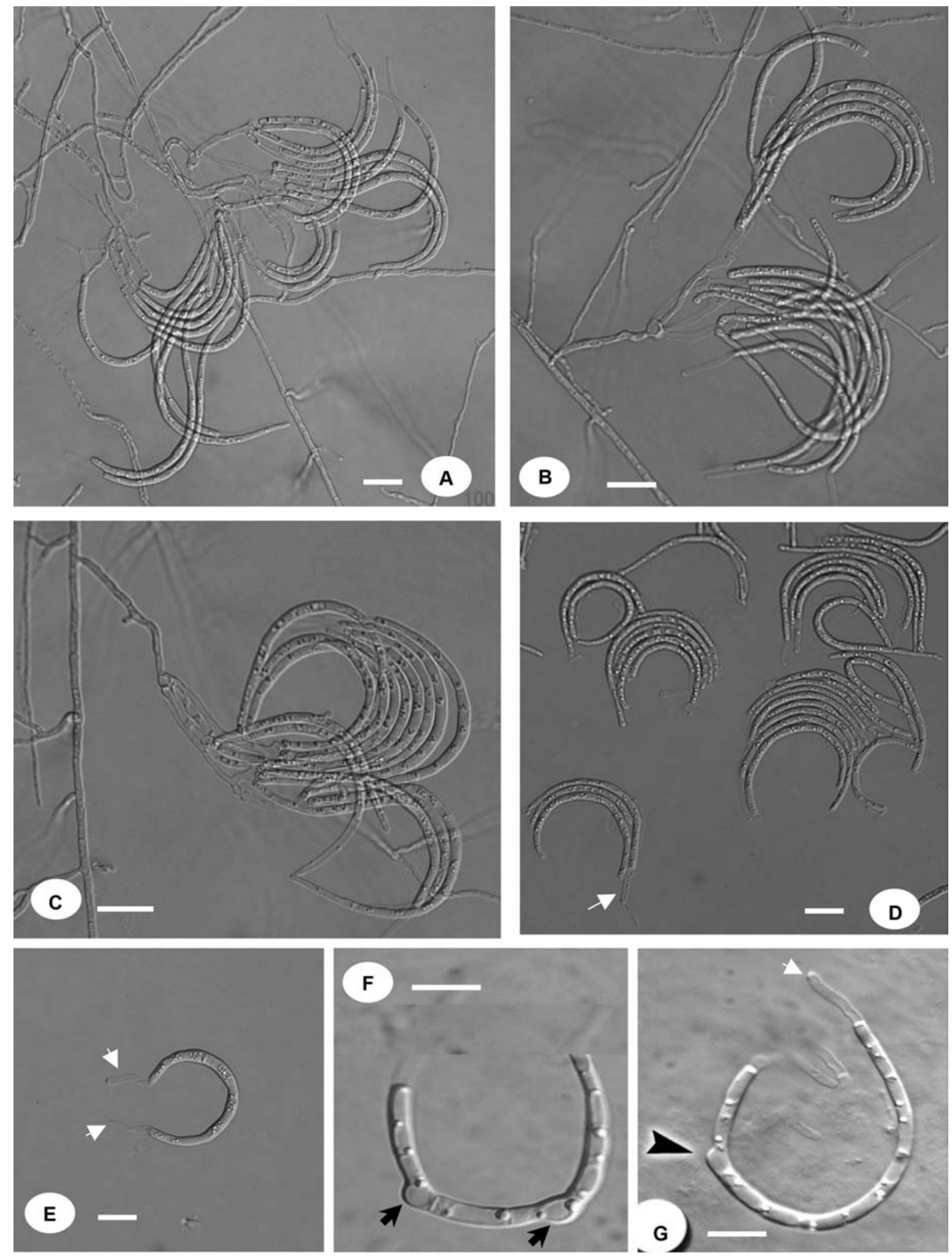

Figure 4 Halosigmoidea parvula.

(A, C, D) Conidiophores bearing conidiogenous cells. (B, E-G) Conidia with empty end cells. Protrudence at septa arrowed. Scale bars: $10 \mu \mathrm{m}$.

mosae adsunt. Conidiophori longi 2.0-60 $\mu \mathrm{m}$, lati 2-3 $\mu \mathrm{m}$, inramosi vel paulum ramosi, plerumque longi $20 \mu \mathrm{m}$, cum inramosi, hyalini, paulum septati, pleurogeni, cum tenue pariete sunt. Cellula conidiogena holoblastica terminalis, monoblastica, sympodialis cum denticulis prominentibus vel nonnumquam pariete polita. Conidii (32-)
85-125 (-140) $\mu \mathrm{m}$ longi 3-5 $\mu \mathrm{m}$ crassi, solitari, filiformes, curvati usque ad efficendam volutationem cum 4-8 (-10) septis, plerumque 5 constrictis ad septa, sed interdum. Conidiorum cellulis finem facentibus quandoque deest quod in iis inest; illae obtusae altera base et filiformes altera extrema parte sunt, aut utraque extrema 

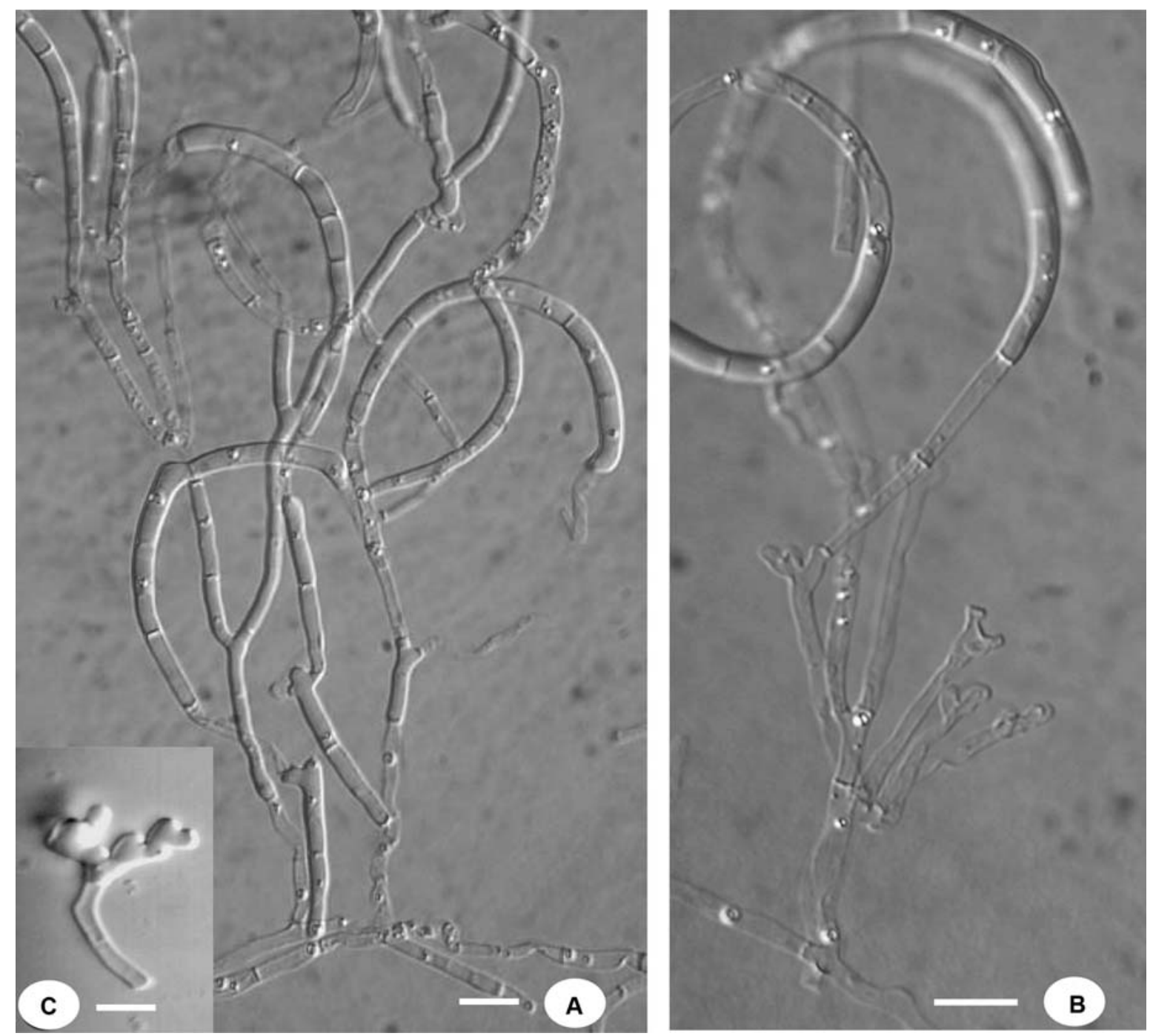

Figure 5 Halosigmoidea parvula.

(A, B) Branched conidiophores with terminal conidiogenous cells. (C) Inset of conidiogenous cells. Scale bars: $10 \mu \mathrm{m}$.

pars filiformis vel utraque obtusa est. Teleomorphis ignota.

Holotypus subspecie coloniae in Centraalbureau voor Schimmelcultures (Utrecht, The Netherlands) depositus (CBS number 114753). Locus classicus in mare Baltico, Germania; holotypus (TUB 6989) e planta aquatica Zostera marina mense Martio 2003 separatus est.

Colonies slow-growing on PDA with natural filtered seawater, $10 \mathrm{~mm}$ diameter within 7 days at $20-25^{\circ} \mathrm{C}$, $3 \mathrm{~mm}$ diameter within 7 days at $14^{\circ} \mathrm{C}$ in the dark. Mycelium on glucose-yeast extract agar medium colorless at first, later pale brown to pale yellow, compact with little aerial mycelium. Conidia are produced in abundance without submergence in water. Hyphae 1.5-2.5 $\mu \mathrm{m}$ in diameter, mostly immersed, hyaline, septate, branched, and not constricted at the septa. Anastomoses sometimes present. Conidiophores $2.0-60 \times 2-3 \mu \mathrm{m}$, simple or sparsely branched, pleurogenous on the mycelium, typically $20 \mu \mathrm{m}$ long when unbranched, hyaline, cells one to few, walls smooth and thin (Figures 4A, B and 5A, B). Conidiogenous cells holoblastic, acrogenous, irregularly sympodial, often denticulate at the apex (Figure $5 \mathrm{~A}-\mathrm{C}$ ).
Conidia (32-) 85-125 $(-140) \times 3-5 \mu \mathrm{m}$ (including the ends lacking cytoplasm when present), solitary or in groups, filiform, curved, C- or U-shaped, 4-8 (-10) septate, typically with 5 middle cells slightly constricted at the septa. The terminal cells of mature conidia are sometimes devoid of cytoplasm; the proximal end is mostly obtuse and the distal end filiform, both ends are rarely obtuse or both filiform (Figure 4B, C, E-G). Teleomorph unknown. Mode of life: saprophytic. Substrate: Polysiphonia sp. and Ceramium sp. (Rhodophyta) and Zostera marina.

On media without salt, older mycelium is torulose with chlamydospore-like structures and becomes more darkly pigmented. Young hyphae are 3-4 $\mu \mathrm{m}$, older up to $9 \mu \mathrm{m}$ wide, no aerial mycelium is present. Sporulation rare, with conidia irregularly swollen. Growth is $5 \mathrm{~mm}$ diameter week $^{-1}$ at $20-25^{\circ} \mathrm{C}$ dark.

Holotype A culture derived from type (TUB 6989) has been deposited at the Centraalbureau voor Schimmelcultures (Utrecht, Netherlands) with the CBS number 114753. 

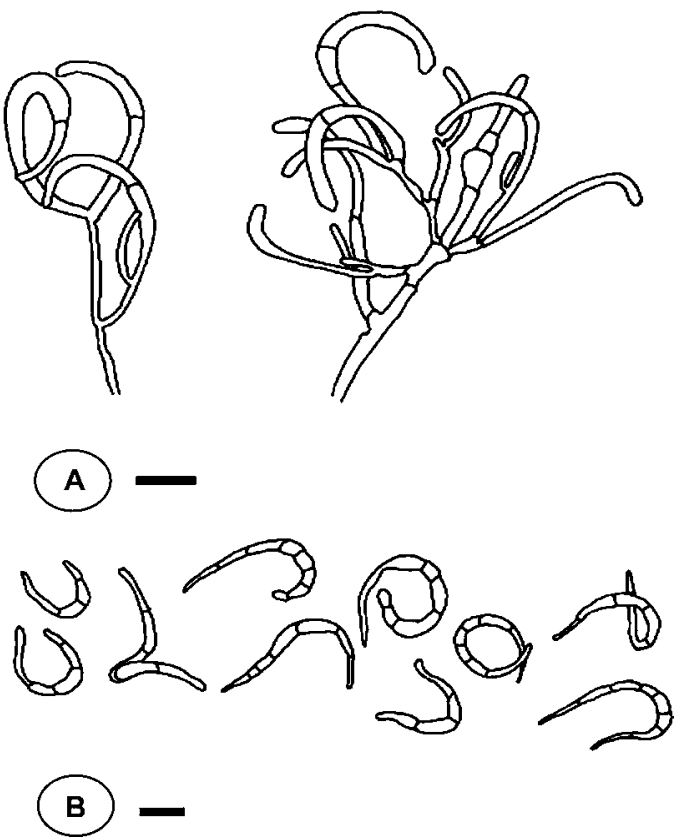

Figure 6 Halosigmoidea parvula: line drawings. (A) Conidiophores and conidia. (B) Conidia. Scale bars: $10 \mu \mathrm{m}$.

Material examined Germany, Wismar Bucht, Zostera marina, March 2003, A. Zuccaro, TUB 6989 (=CBS 114753); Ahrenshoop, Polysiphonia sp. September 2002, A. Zuccaro, TUB 6582; Travemunde, Ceramium sp. May 2004, A. Zuccaro, TUB 407. Japan, Ohya, Motoyoshicho, Miyagi Pref., sea foam, 29 October 1981, A. Nakagiri, NBRC 32159 (=AN-708); Hamanaka, Horoto, Hokkaido, sea foam, 30 Aug. 1984, A. Nakagiri, NBRC 32160 (=AN931); and Sarufutsu, Soya-gun, Hokkaido, sea foam, 22 Aug. 1981, NBRC 103558 (=AN-666).

\section{Key to genera previously assigned to Sigmoidea J.L. Crane}

1. Conidiogenous cells "polyphialidic" enteroblastic....... cendosigmoidea

1. Conidiogenous cells sympodial, holoblastic and denticulate.

2. Conidial end cells lacking cytoplasmic contents, conidia C- to U-shaped, colonies colored and slimy, marine.......................................Halosigmoidea

2. Conidia sigmoid, end cells with contents, freshwater..............................................Sigmoidea.

\section{Key to Halosigmoidea species}

1. Colony bright yellow, conidia 106-223 $\mu \mathrm{m}$ long, 5-8 $\mu \mathrm{m}$ wide near the middle, 7-13 (-18) septate ..Halosigmoidea luteola

1. Colony hyaline to pale yellow with age ...................2

2. Conidia (32-) 85-125 (-140) $\mu \mathrm{m}$ long, 3-5 $\mu \mathrm{m}$ wide near the middle, 4-8 (-10) septate .Halosigmoidea parvula

2. Conidia (80-) 110-180 (-231) $\mu \mathrm{m}$ long, 4-7 $\mu \mathrm{m}$ wide near the middle, 7-11 septate Halosigmoidea marina.

\section{Acknowledgements}

We thank Dr. Ludmilla Marvanová for a culture of Sigmoidea prolifera (CCM F-10002) and for valuable comments on various drafts of this manuscript; Mariella Pratissoli for help with the Latin text; Drs. Barbara Schulz and Sigfried Draeger are acknowledged with gratitude for supplying some of the cultures used in this study; to BRT for financial support (research grant BRT_245002); to the Graduate School of Songkla University; to the Thailand Graduate Institute of Science and Technology (TGB-11-22-18 509D) for a research scholarship to I.C.; to BIOTEC, Thailand for a postdoctoral fellowshhip to Dr K.L. Pang; to Prof. Morakot Tanticharoen, Drs. Ruud Valyasevi and Kanyawim Kirtikara for continued support and to two anonymous reviewers for their valuable comments.

\section{References}

Abdel-Wahab, M.A., T. Nagahama and F.A. Abdel-Aziz. 2009. Two new Corollospora species and one anamorph based on morphological and molecular data. Mycoscience 50: 147-155.

Ando, K. and N. Nakamura. 2000. Pseudosigmoidea: a new genus for a hyphomycete (ATCC 16660) formerly identified as Sigmoidea prolifera. J. Gen. Appl. Microbiol. 46: 51-57.

Bunyard, B.A., M.S. Nicholson and D.J. Royse. 1994. A systematic assessment of Morchella using RFLP analysis of the $28 \mathrm{~S}$ ribosomal RNA gene. Mycologia 86: 762-772.

Campbell, J., C.A. Shearer, J.I. Mitchell and R.A. Eaton. 2002. Corollospora revisited: a molecular approach. In: (K.D. Hyde, ed) Fungi in marine environments. Fungal diversity research series 7. Fungal Diversity Press, Hong Kong. pp. 15-33.

Crane, J.L. 1968. Freshwater hyphomycetes of the Northern Appalachian highland including New England, and three Coastal Plain States. Am. J. Bot. 55: 996-1002.

Descals, E. and J. Webster. 1982. Taxonomic studies on aquatic hyphomycetes III. Some new species and a new combination. Trans. Br. Mycol. Soc. 78: 405-437.

Haythorn, J.M., E.B.G. Jones and J.L. Harrison. 1980. Observations on marine algicolous fungi, including the hyphomycete Sigmoidea marina sp. nov. Trans. Br. Mycol. Soc. 74: $615-623$.

Hsieh, S.-Y., S.T. Moss and E.B.G. Jones. 2007. Ascoma development in the marine ascomycete Corollospora gracilis (Halosphaeriales, Hypocreomycetidae, Sordariomycetes). Bot. Mar. 50: 1-12.

Jones, E.B.G. 1995. Ultrastructure and taxonomy of the aquatic ascomycetous order Halosphaeriales. Can. J. Bot. 73 (Suppl. 1): S790-S801.

Jones, E.B.G., R.G. Johnson and S.T. Moss. 1983. Taxonomic studies of the Halosphaeriaceae: Corollospora Werdermann. Bot. J. Linn. Soc. 87: 1-20.

Jones, E.B.G., I. Chatmala and K.L. Pang. 2006. Two new genera isolated from marine habitats in Thailand: Pseudolignincola and Thalespora (Halosphaeriales, Ascomycota). Nova Hedwigia 83: 219-232.

Jones, E.B.G., J. Sakayaroj, S. Suetrong, S. Somrithipol and K.L. Pang. 2009. Classification of marine Ascomycota, anamorphic taxa and Basidiomycota. Fung. Divers. 35: 1-189.

Landvik, S. 1996. Neolecta, a fruit-body-producing genus of the basal ascomycetes, as shown by SSU \& LSU rDNA sequences. Mycol. Res. 100: 199-202.

Marvanová, L. 1986. Three new hyphomycetes from foam. Trans. Br. Mycol. Soc. 87: 617-625.

Marvanová, L. and E. Descals.1987. New taxa and new combinations of aquatic hyphomycetes. Trans. Br. Mycol. Soc. 89: 499-507. 
Marvanová, L. and N.L. Hywel-Jones. 2000. Sigmoidea contorta sp. nov. and two rare hyphomycete species from streams in Thailand. Crypt. Mycol. 21: 13-26.

Nakagiri, A. 1989. Marine fungi in sea foam from Japanese coast. IFO Res. Commun. 14: 52-79.

Nakagiri, A. and K. Tubaki. 1982. A new marine ascomycete and its anamorph from Japan. Trans. Mycol. Soc. Jpn. 23: 101110.

Petersen, R.H. 1963. Aquatic hyphomycetes from north America III. Phialosporae and miscellaneous species. Mycologia 55: 570-581.

Rambaut, S. 1999. Se-Al [online]. Department of Zoology, University of Oxford, Oxford. Available from http://evolvezoooxacuk/Se-Al/Se-Alhtml [cited 18 November 2001].

Swofford, D.L. 2002. Phylogenetic analysis using parsimony. Version 5. Sinauer Associates Inc. Publishers, Sunderland, MA.
White, T.J., T. Bruns, S. Lee and J. Taylor. 1990. Amplification and direct sequencing of fungal ribosomal RNA genes for phylogenetics. In: (M.A. Innis, D.H. Gelfand, J.S. Sninsky and T.J. White, eds) PCR protocol: a guide to methods and applications. Academic Press, San Diego, CA. pp. 315-322.

Zuccaro, A. and J.I. Mitchell. 2006. Fungal communities of seaweeds In: (J. Dighton, J.F. White and P. Oudemans, eds) The fungal community. CRC/Taylor and Francis, New York. pp. 533-579.

Zuccaro, A., B. Schulz and J.I. Mitchell. 2003. Molecular detection of ascomycetes associated with Fucus serratus. Mycol. Res. 107: 1451-1466.

Zuccaro, A., C.L. Schoch, S. Draeger, W.J. Spatafora, J. Kohlmeyer and J.I. Mitchell. 2008. Detection and identification of fungi intimately associated with the brown seaweed Fucus seratus. Appl. Environ. Microbiol. 74: 931-941.

Received 12 November, 2008; accepted 26 May, 2009 
Copyright of Botanica Marina is the property of Walter de Gruyter GmbH \& Co. KG. and its content may not be copied or emailed to multiple sites or posted to a listserv without the copyright holder's express written permission. However, users may print, download, or email articles for individual use. 